\title{
E-LEARNING MEDIA FOR RETAKERS IN ACHIEVING LEVEL OF GRADUATION COMPETENCE NURSE INDONESIA TEST IN SOUTH BORNEO
}

\author{
Mohammad Basit ${ }^{1}$, Dini Rahmayani², Esy Andriani Sambe ${ }^{3}$ \\ ${ }^{123}$ Stikes Sari Mulia Banjarmasin \\ Email: syafabasit@gmail.com, dinirahmayani@yahoo.com, esyandri@gmail.com
}

\begin{abstract}
Introduction: At present the number of students who do not pass the Indonesian Nurse Competency Test (UKNI) or as a retaker is very high. Various types of programs have been carried out but the level of graduation achievement for retakers has not achieved maximum results. This is because retakers are far from the reach of Educational Institutions, so that in the process of coaching such as tutoring becomes less intensive. Therefore, currently there is a need for distance learning media such as the E-learning method for retakers. Methods: this research used the Pre Experimental Design with One Group Pretest -posttest, with 59 samples of retakers in South Kalimantan. Data collection uses observation techniques with analysis using the Wilcoxon Test. Results: of the Wilcoxon test showed a significance value $=0,000$ (<0.005), indicating that there were differences in the results of the Graduation Rate on the pretest and posttest results before and after tutoring using a smartphone-based e-Learning method. The average results of the Indonesian Nurse Competency Test followed by the retakers who were respondents in the July 2018 period were declared competent there were 16 retakers (27.1\%). Conclusions: the distance learning with E-learning method that utilizes smartphone applications is very effective to be used to increase the graduation rate of retakers in UKNI. This effectiveness is also supported by the maximum interaction between educators and retakers, between retakers and various educational facilities.
\end{abstract}

Keywords: E-learning, UKNI, Retaker, Tutoring.

\section{INTRODUCTION}

A low percentage of students who pass the competency exam should be an evaluation material for educational institutions. Referring to the letter circulated by Kemenrisetdikti number 1258 / E.E3 / DT / 2013, students who have not passed the competency test can take the competency test (repeat) as retakers, whose implementation is made according to the schedule determined by the National Competency Test and Higher Education National Committee (Study Program ) still has an obligation to provide guidance to Respondents who have not passed the competency exam / retakers; which means that the retakers of alumna who have not passed the competency test are still required to be accompanied and trained properly and seriously. Indeed this has become a consequence and at the same time the double burden for each educational institute is a joint response. Based on data from the results of the Indonesian nurse competency test announcement in the March 2018 period, in 5 private higher educational institutions in South Kalimantan totaling 565 registered in the UKNI and participants who were declared competent were 258 participants and were not competent were 307 participants.

From the results of a short interview to 5 Higher Education Institutions in the Province of South Kalimantan it can be concluded that almost all institutions carry out tutoring in first taker participants. implemented for prospective competency test participants for \pm 1 -2 months before the time of the implementation of the competency test. Learning guidance is carried out by enriching the material and giving debriefing to competency test participants in future by carry out practice questions and problem analysis. The lecturer gives tricks on the execution of the questions, invites the participants to examine and analyze the questions. But sometimes the problem is that some retakers who have returned to the village have some obstacles to being able to attend the tutoring process due to the considerable distance, time, busy to work, a low motivation to take competency test and considerable costs. The above retakers problems need the attention of all parties, both Dikti as a government representative institution, AIPNI as a Nurse Association, PPNI as a nurse organization, and Educational Institutions that have educated, have great responsibilities, therefore must have the right strategy to facilitate the retakers to can get 
tutoring before they take the competency test. One way to solve the problem is distance learning, called E-Learning. E Learning is an online learning process whose implementation is supported by telephone, audio, transmission, and computers Kusmana Ade (2011).

\section{METHODS}

The type of research used is quantitative research with a pre-experimental design one group design pretest and posttest, this study is relatively simple, because the research subjects were single groups and did not have a control group. As a variable in this study is the learning process as an independent variable and the graduation rate as the dependent variable.

The number of samples was taken from participants who will take the Indonesian Nurse Competency Test (UKNI) for the period of July 2018. Where the number of retakers is 307 participants were obtained from 5 educational institutions in South Kalimantan. In this study, sample selection was done using purposive sampling technique, which was chosen according to the sample criteria determined by the researcher. This criterion is the retakers who will take the Indonesian Nurse Competency Test for the period of July 2018, from the Nursing Higher Education in the South Kalimantan region, have a smartphone and are willing to become respondents by filling out an informed consent sheet. From this election 59 retakers were taken as samples in this study.

The research was conducted in four steps, namely:

1. Selection of research samples

2. Stage I: Pretest, by looking at the student graduation rate which becomes the sample of the study before being given a distance learning guide based on a smartphone. This pretest is done using a smartphone-based Computer Based Test (CBT), with the website address http://bee-learningsmukNurse.com (Figure 2).

3. Phase II: all samples in this study were given assistance in the form of distance learning a smartphone application i.e. WhatsApp Mesanger. Every day tutoring is done by sending learning materials in the form of Microsoft words that have been compiled by the Drafting Team. Then on the same day, competency test questions will be discussed which must be answered by retakers who want the research sample. Questions sent in the google form aplication where the links for questions on Google forms are sent via the WhatsApp Mesanger Group. The last is to send the answer key and analyze the answers to the evaluation material for retakers in this study.

4. Phase III: Posttest, by looking at the graduation rate of retakers taken as research samples after being given an smartphone-based distance learning guide. This posttest is done using a smartphone-based Computer Based Test (CBT), with the website address http://beelearningsmukners.com. (Figure 1).

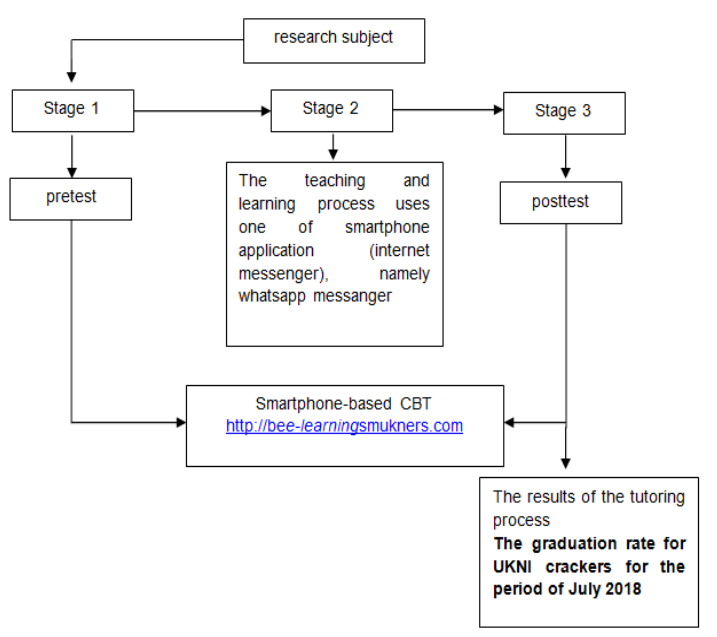

Figure 1. Flow of Research

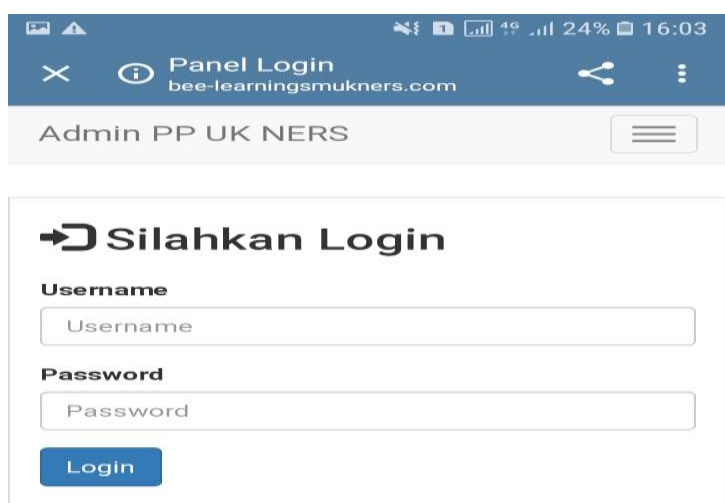

Figure 2. Start page of a Smartphone-based Computer Based Test

Analysis of the data used in this study is univariate analysis by making a table of frequency distribution and bivariate analysis using the Wilcoxon Signed Rank test. The data instrument used is the activity of retakers in the learning process through an observation. The observation sheet is made with the Guttman scale alternative answers "yes" and "no", this observation sheet by the research of Aminoto and Pathoni (2014) and modified by the researcher. To see the graduation rate is to categorize the results of values stored in 
the CBT system that has been managed in such a way by researchers, Alderson (2000).

This research was conducted by STIKES Sari Mulia Banjarmasin, and a research ethics test was conducted at STIKES Sari Mulia Banjarmasin with the research ethics numbers 007/KE-LPPM/STIKES-SM/VI/2018.

\section{RESULTS}

\section{Research Characteristics}

The sample in this study is the retekers of the Indonesian Nurse Competency Test for the period of July 2018 in the five Higher Education Institutions in the Province of South Kalimantan. The number of respondents in this study were 59 respondents who filled out informed consent representing the entire population of retakers in 5 tertiary institutions in the South Kalimantan.

Tabel 1. Characteristics of respondents in beelearningsmukners tutoring

\begin{tabular}{llll}
\hline Variable & Sub variable & Freq & \% \\
\hline Age & 22-26 yearsold & 37 & 63 \\
& 27-31 yearsold & 21 & 36 \\
Gender & 241 yearsold & 1 & 1 \\
& Male & 33 & 56 \\
Address of & Female & 26 & 44 \\
Current & Banjarmasin & 14 & 24 \\
Residence & Outside of & 27 & 46 \\
& Banjarmasin & & \\
& city & & \\
& Outside of & 18 & 30 \\
& South & & \\
The number & Kalimantan & & \\
of & Second & 18 & 30 \\
participating & Third & 9 & 15 \\
in UKNI & Fourth & 6 & 11 \\
& Fifth & 8 & 13 \\
& Sixth & 3 & 6 \\
& Seventh & 4 & 7 \\
& Eighth & 3 & 5 \\
& Ninth & 5 & 8 \\
Origin of & Tenth & 3 & 5 \\
Institution & STIKes SM & 5 & 9 \\
& STIKes SI & 6 & 11 \\
& STIKes CB & 2 & 2 \\
& STIKes DA & 4 & 7 \\
& UMB & 42 & 71
\end{tabular}

From table 1. it can be seen that the majority of retakers in this study were 22-25 yearsold $(63 \%)$, male $(56 \%)$, with residential addresses now outside of Banjarmasin city (46\%), and the majority of number participating in UKNI were the second (30\%), with the institution's origin of each retakers from STIKes SM (9\%), STIKes SI (11\%), STIKes CB (2\%), STIKes DA (7\%), UMB (71\%) .

Percentage of Comparison Results from Respondents who participated in the Pretest and Posttest on Tutoring Study at beelearningsmukners 2018

Tabel 2 Comparative Results of the Pretest and Posttest Values of tutoring study at bee-learningsmukners 2018

\begin{tabular}{lcccc}
\hline \multicolumn{1}{c}{ Values } & $\begin{array}{l}\text { Pre } \\
\text { Test }\end{array}$ & \% & $\begin{array}{c}\text { Post } \\
\text { Test }\end{array}$ & \% \\
\hline $\begin{array}{l}\text { Not } \\
\text { Competent } \\
(\mathbf{0 - 4 7 )}\end{array}$ & 59 & 100 & 31 & 52,54 \\
$\begin{array}{l}\text { Competent } \\
(\mathbf{4 8 - 1 0 0 )})\end{array}$ & 0 & 0 & 28 & 47,46 \\
\hline TOTAL & $\mathbf{5 9}$ & $\mathbf{1 0 0}$ & $\mathbf{5 9}$ & $\mathbf{1 0 0}$ \\
\hline
\end{tabular}

From the data in Table 2. we can see the difference in the value of the Pretest and Posttest graduation after being given equal treatment to all the retakers. These results indicate that there is an increase in the passing score on the Pretest and Posttest results performed on the retakers. Pretest results were obtained before all retakers were treated, from 59 retakers none of the respondents were declared competent $(0 \%)$ and the results of the posttest declared competent were 28 respondents $(47.46 \%)$. This data can show that there is indeed a difference after being given treatment through online guidance on graduation scores.

Tabel 3. Test Results of the Wilcoxon Signed

\begin{tabular}{|l|r|}
\hline \multicolumn{2}{|c}{ Rank } \\
\hline Z & Pretest - Posttest \\
Asymp.Sig. (2-tailed) & -4.818 \\
\hline
\end{tabular}

From the data above, it can be seen that the value of Asymp. Sig. (2-tailed) is worth 0,000, meaning that the value is less than 0.05 .

The Tutoring Graduation Results of the Participants' in bee-learningsmukners 2018 which take the Indonesian Nurse Competency Test in the July 2018

Tabel 4. The tutoring graduation results of the participants' in bee-learningsmukners 
2018 which take the Indonesian Nurse Competency Test in the July 2018

\begin{tabular}{|c|c|c|c|c|}
\hline \multicolumn{5}{|c|}{ UKNI Results in the Period of July 2018} \\
\hline & & & & Cum \\
\hline & & & Valid & Percen \\
\hline & Freq & Perc & Perc & $\mathrm{t}$ \\
\hline Competent & 16 & 27.1 & 27.1 & 27.1 \\
\hline Not & 29 & $49 ?$ & 492 & 763 \\
\hline Competent & & & & \\
\hline $\begin{array}{l}\text { Did not } \\
\text { participate in } \\
\text { UKNI }\end{array}$ & 14 & 23.7 & 23.7 & 100.0 \\
\hline Total & 59 & 100.0 & 100.0 & \\
\hline
\end{tabular}

From table 3 data, it can be seen that the average results of the Indonesian Nurse Competency Test which was followed by respondents in the July 2018 period who were declared competent in the UKNI were 16 reteakers, 29 retakers were not competents $(49.2 \%)$, and those who did not participate in UKNI 14 retakers $(23.7 \%)$.

\section{DISCUSSIONS}

Based on the results of the above research, the characteristics of the research respondents were retekers from various Nursing Education Institutions in South Kalimantan, with an average were 22-25 yearsold and the most gender were men whose majority currently reside outside of Banjarmasin city.

The respondents of this study, the majority of whom came from outside of the Banjarmasin city were interested to participating in the bee-learningsmukners because of the electronic-based learning process. learning is distance learning that utilizes computer technology, computer networks, where learning through computers in their respective places without having to be physically present in class. So that the benefits of E-Learning are strongly felt by retakers, according to rohmah, (2016). The benefits of E-learning are that it can shorten the learning time, make the study costs more economical, facilitate interaction between students and materials, students can access learning materials at any time and repeatedly, the learning process does not only occur in the classroom.

In addition to getting the ease of learning by using the E-learning, retakers also has a strong motivation or motivation in ownslf to obtain Competent results in the Indonesian Nurse Competency Test (UKNI) for the July 2018 period so that the online tutoring process runs well. This is supported by the results of research by Umboh, et al (2017), where motivation has an important role in determining one's learning perseverance. So that retakers has the desire to follow all forms of the learning process in preparation for facing the UKNI. Not only is it easy in the learning process offered by beelearningsmukners Research Team by using the distance learning process using information and communication technology (E-learning) in demand by respondents. The convenience is in the learning process with Asynchronous Training, where the respondent in his treatment is given a test, collecting answers from the test, reading material. Moreover, with this method the respondent does not pay a lot of money for faceto-face tutoring.

The process of learning beelearningsukners uses two online application media namely WhatsApp application and samrtphonebased computer based test. For the pretest and posttest activities using smartphone-based CBT. Participants can directly access the questions via their respective smartphones, the questions tested were 180 questions with a long answer about 3 hours. The content in the CBT application for smartphone based on smartphone is not much different from the UKNI CBT. The goal is to be used as a medium for training the retakers to answer questions, practice speed reading questions, practice improving analysis, practice solving questions for 3 hours, practice answering questions with correct answers at least 100 questions.

In the results of this study a significant increase in the results of the Post test compared to the Pretest results showed that the treatment that the researchers gave turned out to have a positive impact on graduation as indicated by the value of the Posttest of respondents. The treatment given by the researcher is the E-learning learning process that is with an Asynchronous Training where the researcher in each day for 1 month gives a Quis with the Competency Test questions which have been arranged by the Questioning Team according to their field of expertise. The quiz must be answered by the respondent as an exercise in answering. The correct answer and answer analysis is given after the student has finished answering the quiz with the hope that the respondent can learn independently in understanding the Competency Test questions. This is supported by the results of research by Lukmanulhakim and Pusporini (2018), where the high activity and motivation of students in learning are things that need to be considered by students in an effort to achieve high learning achievement. 
During the tutoring process, the learninglearning team, Madurese, always provided motivation to the retakers, so that they were always eager to learn, providing time to study at least 3 hours a day, always playing an active role in every guidance process.

According to Lukmanulhakim and Pusporini (2018), it was explained that the relevance of students' motivation to be active in a series of learning processes, one of which was innovation from various applications of learning methods and the use of multimedia in learning. So from that the E-learning learning process in the treatment in this study is a series of learning programs arranged in an effort to bridge the UKNI participants especially retekers who have returned to the village so they can obtain knowledge through the informatics and communication systems that have developed at this time.

Creating graduates who are qualified and have Competent predicate in UKNI is the task of Educational Institutions in planning and implementing learning processes that focus on students' abilities and willingness. Through this research can be illustrated where the teaching and learning process by focusing on students (Student Center Learning-SCL) has a positive value towards students. Where one of them is by giving a quiz and correcting the right answer with the attachment of the answer analysis as a process of independent learning activities. This is supported by the results of the study of Ardian and Munadi (2015), where students with special abilities have higher creativity when using the SCL learning strategy. One method of learning with the SCL approach is contextual learning, namely discussing concepts (theories) related to real situations and conducting field studies / plunge in the real world to study the suitability of theory (AIPNI, 2013).

As the final result of the study, seen based on the results of the announcement of the Letter of Decision Number: 374 / PUK-Nas / VIII / 2018, (Kemenristikdikti, 2018), it shows that of the majority of research respondents who attended UKNI in July 2018, almost half of the study participants bee-learningsmukners was declared Competent. With that, it can be concluded that the level of success of online tutoring for online learning is successful. However, the success rate of UKNI participants who have become respondents of this study and declared competent is largely in the activity of the respondents in taking tutoring in the research process. Where respondents are active in asking questions and discussing with tutors when there are those who are not understood, looking for literature, always actively answering the questions given, where it becomes the basis that respondents seriously follow the guidance. This is supported by the results of Nugroho's study, (2013) that the effectiveness and success of E-learning learning can be seen from the results of learning and student activity. If the learning outcomes and activeness of students use E-learning is higher than learning that does not use E-learning, then the use of E-learning is said to be effective.

When the tutoring process for UKNI retakers about competency Test questions, many obstacles were encountered, for example internal factors in the level of intelligence in analyzing different questions, lack of enthusiasm for learning, laziness to reread the questions that had been given, lack of focus on following the guidance. While the influence of external factors of friends who are not educative, difficult to use the application, difficult signal, no time to follow the guidelines for working. The implementation of tutoring is not pure using the E-Leraning application, but it combines social media applications because of the limitations of the respondents in understanding the use of the application. According to Kusmana, Ade (2011), students who do not have learning facilities, lack of computer mastery and low motivation to learn will tend to fail.

The use of instructional media in the teaching and learning process is one of the efforts to improve the effectiveness and quality of the learning process which in turn can improve the quality of learning bocer. Based on the results of the study above the learning process using effective e-laerning to support graduation rates. According to Shinta (2011), in teaching and learning activities a teacher must use the right learning method so that learning objectives can be achieved.

\section{CONCLUSIONS}

Distance learning with e-learning method that utilizes smartphone applications is very effective to be used to increase the graduation rate of retakers in UKNI. This effectiveness is also supported by the maximum interaction between educators and crackers, between retakers and various educational facilities.

\section{REFERENCES}

Alderson, J. Charles. 2000. Technology in testing: the present and the future. Elsevier 
E-Learning Media for Retakers in Achieving Level ... (Basit, et.al)

Science Ltd. All rights reserved. System 28 (593-603)

Aminoto, T and Pathoni, H. 2014. Application of Schoology E-Learning Media to Increase Activities and Learning Outcomes of Business and Energy Materials in Class XI of SMA N 10 Jambi city. Jurnal Sainmatika, Vol 8 (1)

Agustina, M. 2013. Utilization of E-Learning as a Learning Media . Yogyakarta: . ISSN: 1907-5022

Ardian, A and Munadi, S. 2015. Effect of Student Centered Learning Learning Strategies and Spatial Ability on Student Creativity. Jurnal Pendidikan Teknologi dan Kejuruan, Vol. 22 (4)

Dahiya, S., Jaggi, S., Chaturvedi, K.K., Bhardwaj, A., Goyal, R.C. and Varghese, C., 2016. An eLearning System for Agricultural Education. Indian Research Journal of Extension Education, 12(3), pp.132-135.

Hakim, A.B., 2016. Effectiveness of Use of ELearning Moodle, Google Classroom Dan Edmodo. I-STATEMENT: Information System and Technology Management (e-Journal), 2(1).

Ilka Zufria. 2016. Use of Digital Media (ELearning) in maximizing the Teaching and Learning Profession (PBM) in Higher Education, (UIN Sumatera Utara). Vol.6(1)

Kemenrisetdikti. 2018. Student Study Program Competency Test Results from decree No. 374/PUK-Nas/VIII/2018.
Kusmana, Ade. 2011,.E-Learning in learning, educational lanterns, Vol 14 (1), June 2011, UNJ

Lukmanulhakim and Pusporini, L.S. 2018. Analysis of Factors Affecting the Achievement of Graduation for Nurse Program Professional Nurse Competency Tests. Education Horizon. No.2, June 2018

Muhammad, S., 2014. Effectiveness of Web and Conventional Based E-learning Media Learning on Student Learning Success Levels (Case Study of Students of the Faculty of Economics, Bina Darma University Palembang). SNASTIKOM 2014, 1.

Nugroho, S. 2013. The effectiveness of using Moodle-based E-learning in learning on student learning outcomes in the eyes of learning information and communication technology. Semarang

Shinta, K D. 2011. The effectiveness of ELearning as a learning media for ICT subjects in class XI at 1 Depok State High School.

Umboh, E.R., Kepel, B.J., and Hamel, R.S. 2017. Relationship Between Learning Motivation and Academic Achievement in Nursing Science Study Program Students at the Faculty of Medicine, Sam Ratulangi University, Manado. e-Journal Keperawatan (e-Kp), Volume 5(1), May 2017. 